\title{
Causes of Education Wastage and Mitigation Strategies In Public Secondary Schools In Kitui Central Sub County In Kitui County, Kenya
}

\author{
Regina K. Kaume-Mwinzi
}

SOUTH EASTERN KENYA UNIVERSITY

\begin{abstract}
Education is a vital tool in the developmental process of any given nation and therefore a critical examination of any lack thereof is essential for it has a bearing at both individual and national front. The purpose of this study therefore was to investigate the causes of education wastage and mitigation strategies in public secondary schools in Kitui central sub county in Kitui County, Kenya. A case study design was used and qualitative interviewing was used to gather qualitative data. Quota sampling was used to select boys, girls and mixed public secondary schools and further used to select one school from each subgroup. Criterion purposive sampling was used to select two students from the boys' and girls' schools sampled and one boy and one girl from the sampled mixed public secondary school. The sample size was six respondents: 3 boys and 3 girls. The findings revealed that the causes of education wastage in public secondary schools in Kitui central sub county in Kitui County, Kenya are pertinent issues that need concerted effort of the education stakeholders in the region in order to sort them out. The findings further revealed that the mitigation strategies proposed are applicable and can minimize education wastage.
\end{abstract} Submitted 13.08.2016

Revised 10.12.2017

Accepted

15.12.2017

\section{Suggested Citation:}

Kaume-Mwinzi, R.K. (2017). Causes of Education Wastage and Mitigation Strategies In Public Secondary Schools In Kitui Central Sub County In Kitui County, Kenya, International Journal of Academic Research in Education, 3(1), 21-32 DOI: 10.17985/ijare.395654

\footnotetext{
${ }^{1}$ South Eastern Kenya University, Rkmwinzi@yahoo.com
} 


\section{INTRODUCTION}

Education is a vital tool in the developmental process of any given nation and therefore a critical examination of any lack thereof is essential for it has a bearing at both individual and national front. Education is considered the root to economic prosperity, the key to scientific and technological advancements, the means to combat unemployment, the foundation of social equality, equal wealth distribution and the spearhead of political socialization and cultural diversity (Psacharopolous, 1998).

There has been a widespread belief among educational economists according to Ojiambo (2009) that educational development would lead to accelerated economic growth, more wealth and income distribution, greater equality of opportunity, availability of skilled human power, a decline in population growth, long life, better health outcomes, low crime rates, national unity and political stability.

This belief has made many individuals and nations invest immensely in education. Expounding further on this belief, Ojiambo (2009) argues that the wealth of nations depend on their capacity to develop their human resources and not so much on their physical resources. He says that a country which is unable to develop skills and knowledge of its people and to utilize them efficiently in the national economy will be unable to develop anything else.

The recognition of the noble role of education in society has led to the concerns of the quality of education as provided in the school, family and society. In Kenya despite the enormous investment in education, the enterprise has been accused of various predicaments which include the widening of the gap between the rich and the poor due to school dropout rates. In 2009, the secondary school net enrolment rate was approximately 50\% of the expected number (World Bank, 2009). The 2005 Kenya Integrated household budget shows that an average secondary school expenditures account for approximately 55\% of annual per capita household expenditures which is a pressing burden for parents (Glennster, Kremer, Mbiti \& Takavashara, 2011)

Over the years, the Kenya government has vigorously expanded access to quality and relevant system of education which also offers equal opportunity to all, thereby ensuring equity. Access to education means adequacy of opportunities available to persons who wish to enter the education system. Although the Kenya government labors to provide access of education to all, the equity which is fairness in participation in education at the public secondary school is elusive.

It is therefore in the light of this scenario that this study critically examines the various causes to education wastage of students in public secondary schools, Kitui Central sub County and the mitigation strategies in order to minimize the education wastage.

\section{Concept of education wastage}

Macro-economic performance and demographic dynamics are major factors influencing the development of the education and training sector of any country (MOE, 2012). It further states that sustainable economic growth and development generally facilitates the sustainable provision of education, whereas large regional inequalities and low economic performance constrain it. Both population growth and the dynamics of the labour market impact significantly on the demand for schooling, whilst improved access to quality schooling and training is fundamental to human and economic development and elimination of poverty.

Glennerster, Kremer, Mbiti and Takavarasha (2011) say that education is widely seen as one of the most promising paths for individuals to realize better, more productive lives and as one of the primary drivers of national economic development.

Improved secondary education is fundamental to the creation of effective human capital in any country and the world conference on education held in Jomtien in 1990 highlighted the need to provide equal opportunity in education (Mumina, 2011). However, the Education For All (EFA) goals have remained elusive in both developed and developing countries.

Indeed, school completion rates have remained low. The question of provision of equal opportunities in education as well as ensuring the number of students who enroll at a cycle and complete it has been the concern of many governments worldwide (Kimatu, 2007).

UNESCO (2004) notes that, worldwide $6.0 \%$ of primary students repeat a grade and in secondary schools, the highest repetition rates are observed in West and Central Africa (18.8\%), the 
Middle East and North Africa (12\%), in Eastern and South Africa (12.3\%). The survey also noted that repetition rates in developing countries are often quite high and the highest rate being in sub-Saharan Africa countries where each year about $22 \%$ of primary students and $21 \%$ of secondary school students were repeating their grade, with the situation being worst in secondary schools of Congo (30.8\%) and Algeria (27.2\%).

In Europe, according to the studies conducted by the Commission Staff Working Party (2010), the Education Council set itself in 2003 a benchmark to reduce the European Union (EU) average rate of Early School Learning (ESL) to not more than $10 \%$ by 2010 . In 2009 , the ESL rate stood at $14.4 \%, 18 \%$ reduction compared to the year 2006. With a drop of 3.2\% points in nine years, progress had been significant: the number of early school leavers had been reduced by almost 1.5 million. Nevertheless, progress had been insufficient to reach the $10 \%$ target by 2010 . The Council therefore, renewed its commitment to the $10 \%$ benchmark with a new target date of 2020 . To reach this target, the reduction rate of ESL needs to accelerate significantly.

Early school leaving is a failure to complete upper secondary school, a failure to complete compulsory schooling or a failure to gain qualifications or school leaving certificate (Commission Staff Working Party, 2010). At EU level ESL rates are defined by the proportion of the population aged 18-24 with only lower secondary education or less and no longer in education or training. Early school leavers are therefore those who have only achieved pre-primary, primary, lower secondary or a short upper secondary education of less than 2 years and include those who have only a pre-vocational or vocational education which did not lead to an upper secondary certification.

Early school leaving has been increasingly recognized as one of the main challenges faced by European societies (Commission Staff Working Party, 2010). For the majority of young people, leaving education and training prematurely is both a result of educational, psychological and social problems and a cause of continuous social insecurity. European education and training systems lose hundreds of thousands of young people each year who are then equipped with inadequate skills for later life. However, reducing ESL to less than $10 \%$ by 2020 is a headline target for achieving a number of key objectives in the Europe 2020 strategy.

The study further reveals that over $70 \%$ of early school leavers in the EU complete only lower secondary education. A very worrying fact is that $18 \%$ of early leavers in EU have completed only primary education and this trend is especially strong in Bulgaria 38\% and Portugal $40 \%$.

Secondary school enrolment rates in Sub-Saharan Africa (SSA) continue to be the lowest in the world. Of approximately 104 million secondary school age children in the region, only one in four (25\%) were enrolled in secondary school in 2006 (UNESCO, 2008). While initial access to education is increasing in many countries, dropout rates continue to be high and this seriously affects Millennium Development Goals (MDGs) and Education For All (EFA) goals (Hunt, 2008).

In many African countries the largest number of out-of-school children are drop outs but gross and net enrolment rates can conceal high levels of attrition and true completion rates can be difficult to measure. Moreover, there are risks that high levels of enrolment growth as a result of improvements in initial access may be achieved at the cost of high levels of drop out (Hunt, 2008).

The delivery of secondary education in Kenya has been marked by numerous challenges some of which have culminated in wastage. This wastage has resulted from non-enrolment, declining retention and completion rates, grade repetition and dropout in schools. These forms of wastage will hamper the attainment of EFA goals which the government targets to meet by the year 2015 (Gachugi, 2011).

Dropout rates and repetition rates provide a way to examine the overall quality of the secondary school system in Kenya. Data show that approximately 92\% of the form 1 class in 2004 reached form 4 in 2007 (MOE, 2009). This was a marked improvement over the previous year where the progression rate for that cohort was $87 \%$. As repetition rates were less than $2 \%$ in 2003 , it is likely that much of the nonprogression of students was actually by dropout rather than repetition rates.

The citizens and the government of Kenya have invested heavily in improving both the access and quality of education in an effort to realize the promise of education as well as to achieve the education-related Millennium Development Goals and vision 2030. However, the secondary school cycle in Kenya faces challenges which include high cost of learning and teaching materials, school uniforms, transport and development levies, extra expenses for private tuition and rising repetitions rates and all these lead to an estimated dropout rate of $30 \%$ (Republic of Kenya, 2002). 
The economic consequences of wastage in secondary schools are myriad and severe. Dropouts don't get the governments fund allocation to the sector in recent years; advances in technology have fuelled the demand for a highly skilled labor force, hence, transforming high school education into a minimum entry into the labor market. Further, secondary school completion has become a basic prerequisite for higher education, meaning that a dropout who joins the labour market will have low earning profiles because they are likely to work at unskilled jobs or at low paying service occupations offering little opportunity for upward mobility. Dropping out also severely impairs a young person's job prospects and earning potentials and in turn causes other secondary indirect problems such as low selfesteem and reliance on public assistance (Goodland \& Anderson, 1987).

\section{PURPOSE OF THE STUDY}

In Kenya due to political interference in the education process, policy environment has been characterized by lack of popular consultation, with decrees, circulars and political rhetoric replacing policy-making apparatus and education sector has been seriously affected. This over the years has initiated uneasy relationship between the political establishment and various educational stakeholders and has had a negative impact on policy formulation and implementation of educational programs (Amutabi, 2003)

Despite heavy investment in education by the government and various players, the corresponding educational indicators in school participation and achievement have been on the decline signifying limited returns on investment. Some of the critical challenges facing education system and particularly at the public secondary school level include declining enrolment and participation rates, low transition rates, declining gross enrolment rates (GER), widening gender and regional disparities particularly in the Arid and Semi-arid lands (ASAL), declining quality and relevance of education, the rise in the costs of education and training, under enrolment of the handicapped and gifted students and inefficiency, poor governance and management of educational structures and institutions (Ojiambo, 2009)

Each of these challenges culminates into education wastage and therefore this research would unearth the possible ways to curb the wastage.

The study aims to help the policy makers in the county and national government to understand the phenomenon of education wastage and its causes so as to put proper strategies for its management. It would also provide a tool kit that supports the development of consistent and comprehensive policy for reducing education wastage in the areas of jurisdiction of these governments. The study would further sensitize all the education stakeholders on education wastage in order to develop mechanisms for prevention, intervention and compensation as mitigation measures for this wastage. Finally the study would pose a challenge for further research by other researchers interested in the area of study.

The study adopted the achievement ( $\mathrm{n}$-Ach) motivation theory proposed by David C. McClelland (1978) of Harvard University. Achievement motivation is a non-conscious concern for achieving excellence through individual efforts. Such individuals set challenging goals for themselves, assume personal responsibility for goal accomplishment, are highly persistent in the pursuit of these goals, take calculated risks to achieve the goals and actively collect and use information for purposes of feedback. People driven by the achievement motive would like to test themselves against their environment and attain standards of excellence (McClelland, 1978).

The need for achievement can be learned at an early stage, beginning at home and then in school and finally at the place of work and McClelland has provided four steps for encouraging motivation.

- $\quad$ Teaching participants how to think, talk and act like persons with high need achievement.

- Stimulating participants to set higher but carefully planned and realistic work goals for themselves.

- $\quad$ Providing the participants with knowledge about themselves.

- Creating team spirit among participants by encouraging them to learn about each other's success, failures and intentions (Okumbe, 1999). 
In the study, the dropping out of students from schools is a process that begins way before the actual dropping out takes place and therefore, if the students had need for achievement (n-Ach), such would not be an eventuality. This is because the student would have set their goals, have a desire to get good results at the end of the course and be focused to complete the course. This means that such students would withstand the causes of drop out in schools.

Students at risk of dropping out display certain easily identifiable characteristics and if the McClelland's four steps of encouragement are applied then the problem would be lessened. These are working intervention programs and this can assist in changing the mindset of the vulnerable students to resist dropping out from school.

\section{METHOD}

The study used a case study design to collect qualitative data. Qualitative interviewing was used for in-depth interview of the identified cases of students who had dropped out of a public secondary school at one time and were in school. The study was guided by the following research questions: What are the causes of education wastage in public secondary schools? In what ways can education wastage be minimized in public secondary schools?

The questions were unstructured and no specific set of questions were prepared. The conversation was informal but professional and the respondents were allowed to tell their own stories in their own terms. Questions were general and non-directive. However, the researcher wrote all the information and caught all the details as much as can be possible. The sample size was six respondents: three girls and three boys. The quota sampling was used to select three subgroups of public secondary schools in Kitui central sub county: boys, girls and mixed schools. It was further used to select one school from each subgroup.

Criterion purposive sampling was used to pick two students from the boys' and girls' schools and one boy and one girl from the mixed public secondary school sampled. These respondents were selected using criterion purposive sampling because the researcher expected them to have the required information with respect to the research questions in the study. Qualitative interviewing which was guided by the in-depth (unstructured) interview was used and this enabled the collection of qualitative data from the cases of study

The researcher prior to data collection subjected the research tools to an expert to review for validity which is an appropriateness of the tools, processes and data. The deviant case analysis which involves searching for and discussing elements of the data that do not support or appear to contradict patterns or explanations that are emerging from data analysis was done by the researcher to establish the reliability - the replicability of the processes and the results.

The researcher and the participants had face-to-face interaction which yielded bulky data as the in-depth (unstructured) interview took place. In data analysis, the researcher used narrative analysis which comprised organizing the bulky data by cleaning and labelling. The data were also sorted by coding guided by the research questions. The data categories were done according to the identified themes. The presentation was done in narrative form.

During the rapport meetings, the researcher assured the participants that the information they provided would strictly be used for the study and their identity would be kept confidential.

\section{FINDINGS}

\section{The causes of Education Wastage in Public Secondary Schools}

The participants were six (06) students, three girls and three boys, who had been school dropouts at one time and they were currently in school. They were interviewed by the researcher in order to reveal the circumstances that made them dropout of school. For the purpose of this research, pseudonyms were used to identify them: Mary, Rose, Leah, John, Mark and Peter.

In the course of the interview the researcher attempted to gather the participants' histories/backgrounds so as to get a better picture of their situations and each of the participants was willing to reveal their family backgrounds.

Mary is a stagnation case and she is in a mixed day secondary school. She had repeated in form three after doing her Kenya Certificate of Secondary Education (KCSE) and obtained grade D- (minus). She looked quite mature compared to other participants. She told the researcher that she repeated so 
that she improves her grade to $\mathrm{C}$ and above and become a teacher or an accountant "I repeated for a better grade to go to college to make a career in nursing but now I would wish to be a teacher or an accountant."

When the researcher asked her why she did not perform well in the KCSE she looked sad and said that she comes from a polygamous poor family and she had undergone many problems due to poverty. She went further and said that her parents are uneducated and she is a sixth born in a family of seven children and she is the only one of her mothers' children who has gone up to form four "just imagine I am the only one who has seen a secondary school classroom, all my sisters and brothers have only reached standard eight. Although some got good marks and got admission letters, they could not join due to lack of money for fees and other school items."

The researcher wanted to find out how Mary managed to go to secondary school despite the poverty at her home and Mary revealed that her Kenya Certificate of Primary Education (KCPE) results were good and she was invited to join a boarding secondary school and of course that was not to be "I passed my KCPE well and got admitted in a boarding secondary school but I did not go for lack of school fees and money for other school requirements." Faced with this predicament, Mary further revealed that she went out to look for menial jobs which she did for five years until free day secondary schools were started in 2008 and this is what helped her to get into a secondary school classroom after being out of school for five years.

Mary said that Free Secondary Education fund (FSE) was also given a boost by the secondary school bursary from the government though was not enough. She also revealed that during the time she was doing the menial jobs she also made contacts and these came in handy and assisted her with some upkeep needs and she had this to say "when I completed standard eight, I stayed out for five years until the day secondary schools came into existence. In those five years I was employed as house help and at times contracted to sell fresh milk and herbal medicine and I made some good contacts that support me financially now that I am in school."

Mary further revealed that these well wishers are the ones who encouraged her and are supporting her to attempt the KCSE for the second time and see whether she can improve her grade. She is in a day secondary school with the government subsidy and the bursary is also assisting her in financing her education.

When the researcher tried to find out whether Mary realizes that there is wastage in repeating she had this to say "it's quite costly in terms of money, time and even materials. I am also growing old trying to improve a grade and if I don't improve it although I'm working hard to improve it, I would be devastated. Mark you; I will be in a secondary school for six years instead of four years!"

Rose is another participant. She was initially in a boarding girl's secondary school where she studied form one and part of form two and she became pregnant. Both of her parents are primary school teachers and according to her they value education. Her elder brother is in form four this year and her younger twins are in standard eight. She unfortunately got pregnant in form two and her parents made arrangements for her after delivery to go back to a girls boarding secondary school which has a day wing near her home in order to attend the classes during the day and in the evening she breastfeeds her son and performs other duties of a mother.

She is quite happy about this arrangement for she is still catching up with the studies despite the misfortune "I am quite grateful to my parents for being so understanding. When I became pregnant, I was afraid that would be the end of the road with my education but my loving parents gave me a second chance. I am now quite committed to studying that I be able to give my son a good future."

The researcher probed to find out if the there was any loss incurred in the process and Rose had this to say "of course all the items which were bought for boarding facilities were discarded when I left the boarding school and not even to mention the full year's fees which was paid for I left the school towards the end of term two."

Rose revealed further that she is now doing form two work again and this is costly in terms of time and other resources. However, she is happy that she can bond with her son in the evening and during the day continues with her studies. She foresees a better future for both of them; courtesy of her caring parents. 
Leah is another case of drop out from secondary school due to sickness. She comes from a humble background. Both of her parents are alive and their source of income is subsistence farming and they also do manual jobs for the neighbours. She is the first born in a family of six children. After her KCPE results were out she was given an admission letter by a boarding girls' secondary near her home and her parents were okay with that for they could even pay her fees in kind, that is, in materials such as fired wood and labour when needed as she was quoted saying "when I got my form one joining instructions, my father went to see the principal to agree on how he would be paying my fees for he could not afford it all at once and the principal was very kind and allowed him to supply firewood to the school and she also promised him that she would be contracting him to do some manual jobs when they arise in the school and translate it to be my fees. Fortunately, the principal has not been transferred and she has kept her promise."

Leah reveled that she is in form four but she ought to have completed form four last year but due to sickness in form three she left school for a term and this made her repeat the class. On further probe Leah explained that in form three her menses cycle changed and she would bleed heavily for many days and this disturbed her very much. She went to a local health facility but this did not help either and most of the time she felt weak. The disillusionment got in and her performance went down and she decided to give education a break to sort out the sickness problem.

Her mother came for her and as they were leaving, the principal advised them to seek help from a certain hospital in Nairobi which deals with women health problems and now the beaming Leah says

"I really love school and I would be very excited to pass with good grades and that's why I convinced my parents and my teachers that I needed to repeat form three so as to be ready for the form four challenges and here I am in form four and ready to pass and go to one of these famous public universities."

When the researcher wanted to know if there was any wastage in the course of her learning, Leah said that all the materials and money her parents gave to the school when she was in form three the first time was wasted for she repeated the same class and paid again. The teachers also used resources and energy twice for her but it is a worthy cause for she is determined to pass her KCSE well.

John is in a day mixed secondary school and he is in form two. He has one parent, his mother and two siblings who are in primary school. His mother runs a 'kiosk' near their home for her income.

John revealed that he had started his secondary school education in another school which was quite a distance from their home and he was finding it taxing for he was waking up very early and in darkness so as to make it on time. In the evening he would also arrive home in darkness and tired. Although his mother encouraged him and even bought him a bicycle, he detested the idea of going to this school.

At times he would sneak out of school before time and join other boys from the village who do not attend school. Other times he would leave home as if he was going to school but end up in the local market where other boys who have left school were playing the pool table game and he would stay there until evening and go home as if he was from school.

By the time his mother and the teachers came to know of his truancy, he had made up his mind not to continue with education in that school "the distance was too much for me but my mother and the principal seemed not to see that and I decided to call it quits. I left the school in form one in term two and stayed out for the rest of that year, but luckily for me the following year, our member of parliament started this school and I was among the first students to enroll in form one. Now I am in form two, I will make it to a college."

John informed the researcher that the resources were wasted when he enrolled in the first school but did not gain much which would have been the benefits.

Mark is in a boys' boarding secondary school. He is in form three. His both parents are civil servants. He is the second born in a family of three boys. His elder brother completed form four last year and he is awaiting the KCSE results while his kid brother has just joined form one but in a different school.

Mark dropped out of school in form two in another boys' boarding secondary school where he had started his secondary education in form one. When he joined the school, he got into a company of some boys and he was introduced into drugs and by the time they were in form two, the group was always high with drugs and undisciplined. They were not even doing assignments and their performance was poor. They were given suspension letters and this was a shocker to Mark's parents who had not known the lifestyle their son was leading in school. 
The parents decided to discipline their son and told him that instead of wasting his life and time in school, he should stay at home and work at the family shamba for a year and at the end of it he will have made up his mind what he wanted in life. Mark explained further and said "I had not known that my father can be so ruthless when he is hurt. I had no alternative but to reform and beg for forgiveness but it took him a year to agree to get me back to school. It's my mother wholooked for this school for me to repeat form two. I tell you, I am a changed person and I'm determined to complete my secondary education and get a good grade."

Mark regrets that he wasted his time in staying out of school and also wasted his parent's resources by repeating the same class after dropping out but blames this on peer pressure. He said that he wanted to behave like his friends without thinking of the repercussion.

Peter's parents are successful business people and most of the time they are occupied by chasing after business deals. Peter is in a boys' boarding secondary school and in form four. He is the only boy in the family and the other children are two older sisters who are in college and doing part-time business of their own.

Peter is a case of stagnation. He repeated form three due to unsatisfactory performance. The teachers felt that Peter was not working hard in class and if he was allowed to register for the KCSE with that kind of attitude and performance he would fail and affect the school's mean grade. His parents were invited to discuss the issue with the subject teachers and in the process it emerged that the parents did not have time to talk about school performance with Peter and he had this to say about it "my class teacher was unhappy with my parents when he realized that they only pay fees and give me pocket money but don't discuss with me anything about my report form or school work." This explanation reveals that Peter's parents do not offer emotional support for their son in order to do well in school and as such Peter repeated form three in order to get ready for the final year in secondary school. This was the initiative of the teachers.

The parents had all the time to do business and paid fees and other upkeep requirements but had no time for moral support of their son and due to their negligence Peter feels that teachers time and energy had been wasted when he went through form three course twice not to mention the parents money and other school resources. However, he says that he has woken up and he will not disappoint his dedicated teachers.

\section{Ways in which education wastage can be minimized in public}

\section{Secondary schools}

In the course of the interview the researcher tried to get the ways of minimizing the education wastage from the participants. Each of the participant acknowledged that there are other students they know of who went through similar situations and some left the school completely and they are living miserably in their villages.

Mary said that if it were not for poverty at her home she would have gone to the school of her dream and performed well. She would be elsewhere today. She advised that the government secondary school bursary should be increased and be managed well so that the allocation should be to all the bright and needy students so as to enable them attend the secondary schools they have merited in the form one admission "today I know of a girl from my village who has been admitted in a boarding secondary school but she is not going for her parents are poor and if the bursary is available for her she would go. She is depressed."

Mary feels that no situation is permanent and if the government is keen on eliminating poverty from its citizens, then through the chiefs' barazas or otherwise, the community can be educated and encouraged to start small businesses through microfinance loans. They can also be encouraged to do productive farming and educated on the benefits of small families.

Rose suggested that the schools should have functional guidance and counseling departments which would be helping students to adjust to the boarding secondary school environment. Moreover, sex education should be a seriously taught subject/topic in school so that the teenagers know who they are and the changes taking place in their bodies. 
She lauded the idea of pregnant girls being allowed to class again "I am quite thankful to all those involved in my being in school again. I will not make such a mistake again." She called upon the parents whose daughters make such mistakes to support them to claim their position in the society through education.

Leah performed poorly in school due to ill-health and says "if I had balanced diet as I came to learn from the hospital, I would not have repeated." She advocates for government's support for food security. Thus, she said that if the farmers are provided with technical know- how in farming and small loans, then malnutrition or imbalanced diet would not arise and healthy children would go to school and study well. Besides the public health facility lacks most of the requirements.

Leah said that if such facilities are equipped well her problem would have been sorted out at the onset and she would not have left school to come back and repeat.

John was apt with the suggestion. He said that day secondary schools should be increased and be located within a walking distance of the students and if the school is at a long distance, then the students walking that long distance will not learn effectively for they will be exhausted.

He said that if the school is located within reach, the truancy/indiscipline may not arise since the parents can also monitor the movement of their children "let the government and other stakeholders open day secondary schools within each catchment area for students to reap maximum benefits."

Mark regrets why he got himself involved with drugs abusers and he advises that the school administrators should empower and strengthen the guidance and counseling department for the teachers to be more vigilant in assisting students to avoid such evils. He further said that religious leaders should be incorporated in students' affairs in order to take care of the students' morals.

However, he said that drug users in schools are hard-cores and in- disciplined. They are out to spoil innocent students so they should be discontinued from school for they would ruin others "these are hard nuts to crack and they should be excommunicated immediately they are identified. They are spoilers."

Peter reported that for a child to do well in school, the parents' both financial and moral support is very important. He said that if his parents had time for him to talk about his studies probably he would have done better and avoided the present predicament.

He suggests that parents should be fully involved and supportive of their children in order to perform well in school "this would make the child put a lot of effort to perform well and avoid repeating." He said that family support is quite crucial and it can also tame the indiscipline tendencies.

\section{DISCUSSIONS AND CONCLUSIONS}

The major findings in this study which used narrative analysis were based on two research questions.

On the causes of education wastage in public secondary schools, the participants came up with the causes; from the narration of the interviewed six cases of dropout and stagnation (repetition), the following emerged as the causes of education wastage:

- Poverty

- Lack of school fees and money for other school requirements

- Need to improve grades/performance

- Pregnancy

- Sickness

- School location /distance

- Truancy /in discipline

- Drugs

- Peer pressure

- Lack of family support

These findings concur with the findings by Tamanna (2014) in Malaysia in which the following reasons for students to drop out of secondary school are revealed.

- Lack of interest in for school

- Cannot afford the fees and expenses

- Poor academic performance

- $\quad$ Need to work to support family 
- Need to take care of family members

- Expelled from school

- No transport to school

The findings further revealed that lack of interest for school is the major reason for dropping out of school and this is revealed to be closely related to truancy which is experienced because students do not like the teachers or they find the way subjects are taught to be uninteresting. The other main reasons are financial constraints; inability to afford school related expenses such as transport fare, school uniforms and shoes, books and stationary, pocket money and food; and poor academic performance.

Both reasons are multifaceted and interrelated with lack of interest and could be due to a myriad of push-factors such as poor pedagogy, lack of literacy or inability to cope with a transition from vernacular school to the curriculum or language in national schools. Pull-factors such as the need to work to support the family or need to take care of family member could also contribute to a child losing interest and performing poorly at school.

All these factors are essentially a function of poverty and distract a child from learning effectively and staying in school.

The mitigation strategies proposed by the participants to minimize education wastage in public secondary schools in this study were revealed; from the interview, the participants suggested the following as ways of minimizing education wastage in PSS.

- Proper channels for disbursement of bursary to the deserving (bright and needy)

- Increased bursary allocation to individual student

- Community awareness on poverty eradication strategies

- Functional guidance and counseling departments in schools

- Teaching of sex education in schools

- Re-admission of student-mothers

- Government policy on food security

- Equipping of local health facilities

- Increased day secondary schools and in accessible locations

- Incorporation of religious leaders in students' affairs

- Excommunication of drug addicts

- Family support

These findings are consistent with the Ministry of education, Culture and Science (2010) on the approach to dropout prevention in the Netherlands where the reduction of the school dropout has been an explicit policy aim for the Dutch government since the early nineties. One of the national goals was to halve the number of new school dropouts from over 5\% annually in 2002 to $2.5 \%$ in 2012. According to this approach, there is growing awareness that dropouts constitute a significant societal and social problem as well as an individual one and for this reason the Dutch government is not only thinking about the systems and institutions but also focuses on the young people themselves. Therefore, to implement this new approach, the main principles of the drive to reduce dropout rates (Aanval op Schooluitval) program are stipulated as follows.

- Pay closer attention to the transfer from pre-vocational secondary education to secondary vocational education.

- Offer more and better special needs facilities at schools

- Offer students who prefer to work with their hands more scope and more tailored programs

- Provide better career guidance and information, help students choose the right studying program and offer them better counseling.

- Make schools more appealing by offering pupils sports and cultural activities

- Set up 20,000 tailor made programs for school dropouts aged 18 to 23 years for 'competences acquired elsewhere" and make arrangements with large employers aimed at helping students obtain a basic qualification.

The Netherlands ministry of education has concluded performance agreements with local authorities and schools. The goal is to reduce the number of dropouts by half by 2012 and to ensure that the funds provided under the agreements only go to schools since schools are often where the problems 
arise and where the dropout rate can be combated most effectively but schools can call on the services of care institutions, the police and the courts via their local authorities (MOE, 2010).

Based on the findings of this research, the following conclusions were made:

- The causes of education wastage in public secondary schools are pertinent issues in the provision of quality education and unless these causes are addressed by all the education stakeholders in this country, a certain percentage of the citizens will miss out on development agenda both at the society and the individual level. In as much as this state of affairs is not controlled, there will be wastage in terms of human capital and other resources.

- The mitigation strategies proposed to minimize education wastage in public secondary schools are quite practical in applicability and if they are given a chance, the percentage of drop out and repetition of students would indeed be minimized and thus minimize education wastage.

- The causes of education wastage in public secondary schools are real and therefore the researcher recommends that the school administration identifies each of these causes at the student individual level and try to address it at that point. Some of the causes to be addressed such as drugs need the involvement of other stakeholders. The parents also should take an active role in supporting their children's education and this would open their eyes to see the right and the wrong of their children's academic life.

The researcher further recommends that the Kenyan government and more so the political class have a duty to its citizens in the provision of quality education and quality life and therefore, there should be proper enforcement of the policies to ensure that even the poor of the poorest have access to education, food and health facility.

- $\quad$ The mitigation strategies to minimize education wastage in public secondary schools if effected are a sure way of maintaining the students in class. The researcher, therefore, recommends that the Parents Teachers Association (PTA), Board of Managers (BOM) and Students Council (SC) now that they are recognized by law as powerful bodies in public secondary school's management in Kenya should stipulate ways of actualizing these mitigation strategies at the individual school level, hence, reduction of education wastage in schools.

\section{REFERENCES}

Amutebi, M. (2003). Political Interference in the Running of Education in Post Independence Kenya: A Critical Retrospection. International Journal of Educational Development 23.

Commission Staff Working Party (2010). Reducing Early School Leaving. Accompanying Document to the Proposal for a Council Recommendation on Policies to Reduce Early School Leaving.

Gachugi, M. (2011). Factors Contributing to Educational Wastage in Public and Private Secondary Schools in Municipality Division, Nyeri District, Central Province Kenya. M.Ed Thesis. Kenyatta University.

Glennster, R., Kremer, M. Mbiti, I., \& Takavasharn, K. (2011). Access and Quality in the Kenyan Education

System: A Review of the progress, Challenges and Potential Solutions. Office of the Prime Minister of Kenya.

Goodland, J., \& Anderson, C. (1987). Improving Access to Schooling in hird World. An overview. Project Bridges. Harvard University.

Hunt, F. (2008). Dropping out from school: A Cross Country Review Literature. Consortium for Research on Education, Access, Transitions and Equity. Retrieved from www.create-rpc.org

Kasomo, D. (2006). Research Methods in Humanities and Education. Zapf Chancery. Eldoret

Kimatu, N. (2007). Wastage in Primary School Education: The Case of Slum Schools in Kibera Division, Nairobi. M.Ed Thesis. Kenyatta University. 
McClelland, D., C. (1978). Managing Motivation to Expand Human Freedom. American Psychologist. 33(3) retrieved from managementstudyguide.com

Ministry of Education (2012). A Policy Framework for Education. Aligning Education and Training to the Constitution of Kenya (2010) and Kenya Vision 2030 and Beyond. Government Printers. Nairobi. Ministry of Education, Culture and Science, Netherlands (2010). The approach to school drop-out. Retrieved from http://www.aanvalopsshooluitval.aal/ usafiles/file/2011029-ocw_vs Ministry of education (2009). Education Management Information Systems.

Mugenda, O. \& Mugenda A. (1999). Research methods: Quantitative \& Qualitative Approaches. Acts press. Nairobi

Mumina, C. (2011). Wastage Rates in Kenyan Secondary Schools: A case of Kathonzweni District, Makueni County. M.Ed thesis. Kenyatta University.

Ojiambo, P. (2009). Quality of Education and its Role in National Development: A case study of Kenya's Education Reforms. Kenya Studies Review

Psacharopolous (1988). Education and Development: A review. World Bank. Washington DC Republic of Kenya (2002). Economic Survey. Central Bureau of Statistics.

Role, E. (2010). Handbook of Social and Educational Research Methods. University of Eastern Africa, Baraton. Kenya

Tamanna, P. (2014). Dropping-out of school in Malaysia: what we know and what needs to be done. Institute for democracy and economic affairs. Policy IDEAS no. 14. Retrieved from www: ideas.org.my

UNESCO (2004). A Statistical Study of Wastage in Schools. Paris. UNESCO. 